\title{
Efikasi Beberapa Agens Hayati Terhadap Penekanan Pertumbuhan Pyricularia grisea Secara In Vitro
}

\section{The Efficacy of Several Biological Agents Against In Vitro Growth Suppression of Pyricularia agrisea}

\author{
Shyntiya Ayu Lestari1), Umi Kulsum²), Evan Purnama Ramdan*3) \\ 1), 3)Department of Agrotechnology, Faculty of Industrial Technology, Gunadarma University, Depok, Indonesia \\ ${ }^{2)}$ Center for Forecasting Plant Pest Organisms, Karawang, Indonesia \\ ${ }^{*}$ Corresponding author: evan_ramdan@staff.gunadarma.ac.id
}

Received: January 29, 2021; Accepted: March 22, 2021; Published: April 1, 2021

\begin{abstract}
The demand for rice as an important food crop in Indonesia is still constrained by the attack of blast disease caused by Pyricularia grisea. Controlling using synthetic chemical pesticides has a negative impact on the environment so that the use of biological agents is an alternative option. This study aims to determine the effectiveness of several biological agents against the pathogen $P$. grisea that causes blast disease in rice plants in vitro. The study used a completely randomized design (CRD) with 6 levels of treatment and was repeated 3 times using the dooble culture method. The results of the study showed that the inhibition of $P$. grisea was the highest in the treatment of $P$. grisea $\times$ Trichoderma sp. and P. grisea $\times$ Gliocladium sp. namely $67.04 \%$ and $51.85 \%$ compared to other treatments. The $P$. polymyxa and $P$. fluorescence treatments showed low inhibition, namely $23.70 \%$ and $28.89 \%$. Biological agents Trichoderma sp. and Gliocladium sp. able to inhibit the growth of the fungus P. grisea. Each biological agent has a different percentage of inhibition in that caused by the inhibitory mechanism of the biological agent.
\end{abstract}

Key words: antagonist test; inhibition; inhibition mechanism

Cite this as: Lestari, S. A., Kulsum, U. \& Ramdan, E. P. (2021). Efikasi beberapa agens hayati terhadap penekanan pertumbuhan Pyricularia grisea secara in vitro. Agrosains : Jurnal Penelitian Agronomi, 23(1), 31-36. DOI: http://dx.doi.org/10.20961/agsjpa.v23i1.48174

\section{PENDAHULUAN}

Indonesia merupakan negara agraris, sebagian besar penduduk Indonesia memiliki mata pencaharian disektor pertanian (Warsani, 2013). Adapun komoditas utama dan unggulan pertanian Indonesia antara lain padi, jagung, kedelai, cengkih, cokelat atau kakao, kapas, karet, kayu manis, kelapa, kelapa sawit, kemiri, kopi, lada, pala, tebu, teh, tembakau, dan vanili (Murjoko, 2017). Pertumbuhan penduduk yang semakin meningkat menjadi tantangan untuk menjaga keseimbangan dalam produksi pangan. Padi (Oryza sativa L.) adalah salah satu tanaman pangan yang diperlukan untuk memenuhi kebutuhan sehari-hari dimana keberadaannya sangat penting dalam kehidupan manusia karena padi mengandung gizi yang cukup bagi tubuh manusia. BPS (2020), produksi padi pada tahun 2019 sebesar 54,60 juta ton gabah kering giling (GKG) dan mengalami penurunan sebesar 4,60 juta ton atau 7,76\% dibandingkan tahun 2018. Penurunan hasil tersebut diakibatkan oleh beberapa faktor dan salah satunya adalah adanya serangan hama dan penyakit pada fase vegetatif maupun generatif sehingga menyebabkan kerugian bagi para petani.

Blas merupakan salah satu penyakit pada tanaman padi yang disebabkan oleh jamur Pyricularia grisea dan menyerang beberapa bagian tanaman padi dengan gejala berupa bercak pada daun (leaf blast), buku batang (node blast), leher malai (neck blast), bulir padi (spikelet blast), dan kolar daun (collar rot), penyakit blas ini mempunyai kemampuan menyerang pada semua fase pertumbuhan tanaman padi (BBPADI, 2015). Gejala berat di bagian buku batang dapat menyebabkan batang padi menjadi patah sehingga menyebabkan kematian bagian batang di atas buku yang terinfeksi (Yulianto, 2017). Sementara itu, penyakit blas leher malai pada varietas rentan dapat mengakibatkan kehilangan hasil sampai 100\% (Suganda et al., 2016). Pada kondisi lingkungan yang mendukung, varietas padi yang terinfeksi parah dengan tingkat intensitas yang tinggi, baik oleh penyakit blas daun maupun blas leher malai, dapat menyebabkan tanaman puso (Nasution \& Usyati, 2015). Penyakit blas pada tanaman padi dapat dikendalikan menggunakan beberapa teknik pengendalian salah satunya adalah teknik budi daya tanaman, penanaman varietas tahan, dan penggunaan fungisida (Yulianto, 2017). Namun, pengendalian yang dilakukan oleh petani umumnya menggunakan fungisida sintetik yang dapat menimbulkan dampak negatif, seperti matinya organisme yang bukan sasaran sehingga berkurangnya keanekaragaman hayati dan membuat lingkungan menjadi tercermar dan menyebabkan ekosistem menjadi terganggu (Yulianto, 2017). Salah satu pengendalian yang ramah lingkungan yaitu pengendalian hayati berbasis mikroorganisme antagonis. Menurut Prasetyo et al., (2017), penggunaan 
mikroorganisme antagonis sebagai agensia hayati berpotensi tinggi dalam menghambat serangan patogen dan mampu beradaptasi serta berkolonisasi pada perakaran tanaman. Pengendalian secara preventif sangat penting dilakukan sehingga dapat mengurangi resiko terjadinya serangan hama dan penyakit yang dapat menurunkan hasil produksi tanaman.

Agens hayati berpengaruh terhadap tanaman, patogen serta lingkungan. Pengaruh agens hayati terhadap tanaman yaitu kemampuan melindungi tanaman dan mendukung pertumbuhan tanaman (Sopialena, 2018). Bagi agens hayati, tanaman menyediakan nutrisi agens dalam bentuk eksudat akar yang diperlukan untuk pertumbuhannya. Pemanfaatan agen hayati untuk menekan pertumbuhan cendawan patogen sudah banyak dilakukan, karena memiliki dampak positif terhadap lingkungan. Aplikasi agen hayati tidak meninggalkan residu, dan menyebabkan resistensi tanaman terhadap penyakit (Zuraidah, 2020). Sementara itu bagi tanaman agens dapat menekan pertumbuhan patogen. Selain itu faktor biotik maupun abiotik sangat berperan dalam kelangsungan hidup agens pengendali hayati seperti suhu, $\mathrm{pH}$, kelembaban, dan beberapa komponen lainnya (Sopialena, 2018). Mikroba antagonis sangat potensial dikembangkan sebagai agens pengendalian hayati (Hasanuddin, 2003). Pengendalian hayati menggunakan agen antagonis dengan aplikasi secara berkala pemakaiannya dapat menekan pertumbuhan dan perkembangan patogen untuk jangka waktu yang relatif panjang tanpa menimbulkan pencemaran lingkungan (Baker \& Cook, 1974; Achmad et al., 2009). Kusumawati \& Istiqomah (2020) telah melaporkan bahwa perlakuan agens hayati mampu menurunkan persentase keparahan penyakit, menurunkan persentase daun yang terserang dana memperpanjang masa inkubasi penyakit blas. Oleh karena itu tujuan dari penilitian ini yaitu untuk mengetahui efikasi beberapa agens hayati terhadap penekanan pertumbuhan Pyricularia grisea skala in vitro.

\section{BAHAN DAN METODE}

Penelitian ini dilakukan dilakukan pada bulan Agustus - September 2020 di Balai Besar Peramalan Organisme Pengganggu Tumbuhan (BBPOPT) Karawang. Adapun bahan yang dibutuhkan dalam penelitian ini adalah bagian padi yang terkena penyakit blas, media PDA (Potato Dextrose Agar), NaOCl 1\%, air steril, Aquades, isolat Pyricularia grisea, isolat agen hayati (Trichoderma sp., Gliocladium sp., Bacillus subtilis, Pseudomonas flourescens dan Paenibacillus subtilis), alkohol 70\%, kertas label, dan media PDA pada petridish. Adapun alat yang dibutuhkan dalam penelitian ini adalah alat dissecting set, laminar dan mikroskop.

Uji antagonis secara in-vitro dilakukan terhadap cendawan Pyricularia grisea yang sudah dimurnikan. Garis diagonal dibuat pada permukaan luar cawan petri yang berisi media Potato Dextrose Agar (PDA). Pengujian dilakukan dengan cara menumbuhkan koloni cendawan secara berpasangan yaitu dengan metode double culture sebanyak 5 perlakuan agens hayati dan 1 perlakuan tanpa agens hayati sebagai kontrol, sehingga terhadap 6 perlakuan (Tabel 1). Masingmasing perlakuan kemudian diulang sebanyak 3 kali. Biakan murni $P$. grisea akan dipasangkan dengan beberapa agens hayati yang sudah ada sebanyak satu ose (diameter $\pm 0,5 \mathrm{~cm}$ ) kemudian diinokulasikan pada cawan petri yang sudah berisi media PDA. Perlakuan kontrol, yaitu $P$. grisea diinokulasikan ke permukaan media PDA di satu sisi tanpa perlakuan antagonis. Pengamatan dilakukan dengan mengukur jari-jari koloni patogen $P$. grisea yang berlawanan arah menuju ke arah Agens hayati. Kemudian persentase penghambatan diukur dengan menggunakan rumus (Mahadtanapuk et al., 2007).

$\mathrm{Z}=((\mathrm{R} 1-\mathrm{R} 2)) / \mathrm{R} 1 \times 100 \%$

Keterangan :

$\mathbf{Z}$ = Presentase penghambatan

$\mathrm{R} 1$ = Jari-jari patogen tanpa antagonis (pada kontrol)

$\mathrm{R} 2$ = Jari-jari patogen dengan antagonis

Tabel 1. Perlakuan uji antagonis beberapa agens hayati terhadap $P$. grisea.

\begin{tabular}{cc}
\hline $\begin{array}{c}\text { Kode } \\
\text { Perlakuan }\end{array}$ & Perlakuan yang diberikan \\
\hline $\mathrm{P0}$ & P. grisea tanpa agens hayati \\
$\mathrm{PgT}$ & P. grisea $\times$ Trichoderma sp. \\
$\mathrm{PgG}$ & P. grisea $\times$ Gliocladium $\mathrm{sp}$. \\
$\mathrm{PgB}$ & P. grisea $\times$ B. subtilis \\
$\mathrm{PgPf}$ & P. grisea $\times$ P. fluorescens \\
$\mathrm{PgPp}$ & P. grisea $\times$ P. polymyxa \\
\hline
\end{tabular}

Penelitian ini menggunakan metode Rancangan Acak Lengkap (RAL) Non faktorial, yang terdiri atas 6 taraf perlakuan yang diulang sebanyak 3 kali yaitu $P 0$, $\mathrm{PgT}, \mathrm{PgG}, \mathrm{PgB}, \mathrm{PgPf}$, dan PgPp. Adapun analisis data yang digunakan adalah sidik ragam (ANOVA). Apabila dalam analisis keragaman menunjukan adanya beda nyata antara beberapa perlakuan beberapa agens hayati terhadap P. grisea maka akan dilanjutkan dengan menggunakan Uji Lanjut Tukey dengan menggunakan taraf sebesar 5\%. Perhitungan dilakukan dengan menggunakan aplikasi SAS.

\section{HASIL DAN PEMBAHASAN}

Berdasarkan uji statitistik semua perlakuan memberikan pengaruh nyata terhadap penghambatan pertumbuhan $P$. grisea (Tabel 2). Daya hambat paling tinggi ditunjukkan oleh perlakuan Trichoderma sp. Diikuti dengan perlakuan Gliocladium sp. berturut-turut sebesar $67.04 \%$ dan $51.85 \%$. Sementara daya hambat paling rendah ditunjukkan oleh perlakuan $P$. polymyxa dan $P$. fluorescence, berturut-turut sebesar $23.70 \%$ dan $28.89 \%$. Pada pengamatan pertumbuhan dari Trichoderma sp. dan Gliocladium sp. yang cepat pada media agar, sedangkan pertumbuhan $P$. fluorescens dan $P$. polymixa yang lebih lambat dibandingkan $P$. grisea (Gambar 1). Kecepatan agens antagonis untuk tumbuh dan beradaptasi dengan lingkungan menjadi salah satu indikator adanya mekanisme agens hayati dalam berkompetisi ruang dan nutrisi dengan patogen. Semakin cepat pertumbuhan agens antagonis maka semakin efektif menekan pertumbuhan patogen. Hal ini sesuai dengan Saylendra et al., (2015) yang menyatakan bahwa mekanisme kompetisi antar jamur terjadi akibat persaingan serta perebutan ruang tumbuh dan makanan yang tersedia. Kompetisi makanan terjadi dalam hal memanfaatkan media tumbuh sebagai sumber makanan. Jamur yang tumbuh cepat lebih unggul dalam penguasaan ruang dan nutrisi sehingga bisa menekan pertumbuhan jamur lawannya (Saylendra 
et al., 2015). Djafaruddin (2000) melaporkan bahwa kecepatan pertumbuhan koloni $P$. fluorescens merupakan salah satu faktor penting dalam menentukan potensinya sebagai agens hayati terhadap patogen. Pertumbuhan koloni $P$. fluorescens juga berperan penting dalam proses siklus hidupnya karena spora atau konidia merupakan alat reproduksi aseksual, penyebaran, dan pertahanan hidup cendawan pada lingkungannya (Elbert et al., 2007).

Tabel 2. Daya hambat beberapa agens hayati terhadap P. grisea

\begin{tabular}{cc}
\hline Kode Perlakuan & Daya hambat $(\%)$ \\
\hline P. grisea tanpa agens hayati & $0 \mathrm{~d}$ \\
P. grisea $\times$ Trichoderma sp. & $67,04 \mathrm{a}$ \\
P. grisea $\times$ Gliocladium sp. & $51,85 \mathrm{ab}$ \\
P. grisea $\times$ B. subtilis & $34,07 \mathrm{bc}$ \\
P. grisea $\times$ P. fluorescens & $23,70 \mathrm{c}$ \\
P. grisea $\times$ P. polymyxa & $28,89 \mathrm{c}$ \\
\hline
\end{tabular}

Keterangan: Angka-angka pada kolom yang sama yang diikuti oleh huruf yang sama tidak berbeda nyata pada taraf uji 5\% (uji Tukey).

Pada penelitian ini terdapat perbedaan presentase penghambatan dalam setiap perlakuan. Hal ini dapat diakibatkan oleh mekanisme penghambatan agens hayati. Hubungan organisme antara agens hayati dengan patogen dapat membantu melalui parasitisme, antibiosis, kompetisi, predasi dan lisis. Mekanisme antagonis dari Gliocladium sp. dan Trichoderma sp. terhadap organisme lain adalah hiperparasitisme, antibiosis atau lisis, maupun kombinasi keduanya (Paulitz, 1992). Di alam, agens hayati dapat memiliki satu atau lebih mekanisme untuk menekan pertumbuhan patogen. Kecepatan pertumbuhan jamur antagonis merupakan indikator mekanisme kompetisi ruang dan nutrisi dengan patogen. Semakin cepat pertumbuhan jamur antagonis maka semakin efektif menekan pertumbuhan patogen (Amaria et al., 2015). Trigiano et al., (2008) menyatakan bahwa kompetisi merupakan mekanisme yang terjadi antara dua atau lebih mikroorganisme yang menggunakan atau memperebutkan makanan (karbon dan nitrogen) atau sumber mineral yang sama. Selain itu, makanisme ini juga terjadi dengan cara kompetisi dalam menempati habitat atau inang yang sama. Mikroorganisme yang satu dapat mengalahkan mikroorganisme lainnya karena pertumbuhannya lebih cepat sehingga dapat menggunakan secara efisien sumber makanannya (Trigiano et al., 2008).

Selain adanya mekanisme kompetisi dan antibiosis, pada penelitian ini juga ditemukan mekanisme parasitisme yang ditunjukkan oleh cendawan Trichoderma sp. dan Gliocladium sp. mampu menghambat pertumbuhan $P$. grisea dikarenakan Trichoderma sp. merupakan jamur yang memiliki sifat parasitisme dan berpotensi sebagai mikroba antagonis dan mengeluarkan zat antibiotik untuk menghambat jamur lainnya. Hal ini sesuai dengan pernyataan Octriana (2016) bahwa Trichoderma sp. dan Gliocladium sp. mengantagonis cendawan Phytium sp. Trichoderma sp. setiap spesies mampu menghasilkan salah satu atau lebih enzim litik, glukanase, selulase, kitinase dan antibiotik antifungal (Octaviani et al., 2015). Selain itu, jamur Trichoderma sp. menghasilkan senyawa kimia yang bersifat toksik dan enzim yang mampu mendegradasi sel patogen (Benitez et al., 2004). Selain menghambat dengan mekanisme parasitisme (Raka, 2006). Persaingan ini terjadi akibat adanya kebutuhan yang sama dari masing-masing cendawan, yaitu kebutuhan tempat tumbuh dan nutrisi media yang digunakan untuk tumbuh tanaman (Dwiastuti et al., 2015). Trichoderma sp. merupakan salah satu jenis mikroba yang memiliki kemampuan dalam menghambat pertumbuhan patogen dengan menghasilkan senyawa aktif biologis secara in vitro. Senyawa aktif tersebut meliputi alkaloid, paxillin, lolitrems, dan tetranone steroid (Dwiastuti et al., 2015). Jamur Trichoderma sp. memiliki kemampuan lebih cepat dalam penguasaan ruang dan nutrisi sehingga dapat menghambat pertumbuhan jamur $P$. grisea (Golfarb et al., 1989). Sedangkan Gliocladium sp. bersifat parasit dan mampu mengeluarkan antibiosis untuk menghambat pentumbuhan dari cendawan, berkompetisi akan makanan, dapat menghasilkan zat penghambat dan bersifat hiperparasit (Papavizas, 1985). Cendawan Gliocladium sp. memiliki laju pertumbuhan yang sangat cepat, jumlah spora yang dihasilkan juga mampu menghambat pertumbuhan cendawan patogen serta cendawan ini menghasilkan senyawa gliovirin dan viridin yang mampu menekan dan menghambat pertumbuhan cendawan patogen (Sopialena et al., 2020). Hal ini sesuai dengan pernyataan Risthayeni \& Zahara (2018) yaitu cendawan Gliocladium $\mathrm{sp}$. memiliki daya hambat yang cukup tinggi terhadap cendawan patogen karena senyawa yang dihasilkan merupakan toksin atau antifungal bagi cendawan patogen.

Bakteri sebagai agen hayati mampu menghasilkan senyawa metabolit yang memiliki efek antijamur. $B$. subtilis mampu menekan pertumbuhan dari patogennya mengeluarkan antibiosis untuk menghambat pertumbuhan jamur lainnya serta mampu mengeluarkan enzim yang bersifat toksik yang bisa menghancurkan jamur (Nur'Aini et al., 2013). Antibiotika yang dihasilkannya antara lain, polimiksin, difisidin, subtilin, subtilosin, protein. B. subtilis mampu menghasilkan enzim degradatif makromolekul yang bisa menghancurkan dinding sel jamur seperti xilanase, kitinase dan protease (Kunst \& Rapoport, 1995). Bacillus subtilis merupakan bakteri yang bersifat kitinolitik yaitu bakteri yang dapat menghasilkan enzim kitinase, sehingga mampu mendegradasi dinding sel cendawan P. grisea (Zuraidah, 2020). Akibatnya dinding sel cendawan melisis dan terhambat pertumbuhannya. Kemampuan suatu senyawa yang terdapat di dalam bakteri dapat mengendalikan jamur sehingga terganganggunya permeabilitas jamur. Hal tersebut dapat menghambat produksi dan ekskresi enzim ekstraseluler dari jamur (Zuraidah, 2020). Menurut Rao (1994), B. subtilis mampu memproduksi antibiotik aterimin dan basitrasin yang sangat beracun bagi patogen. $P$. flourescens mampu menghasilkan antibiotik, dapat memproduksi asam sianida, siderofor, enzim ekstraseluler yaitu kitinase, selulase, dan protease yang melisis sel patogen (Jaganesh et al., 2007). Enzim-enzim tersebut berfungsi untuk mendegradasi selulosa pada jamur $P$. grisea dan menghambat pertumbuhan jamur patogen tersebut. Walaupun selulosa pada $P$. grisea telah didegradasi oleh enzim yang terdapat pada jamur antagonis 
tersebut, $P$. grisea masih dapat tumbuh karena komponen utama dinding sel yaitu kitin pada $P$. grisea tidak mengalami lisis (Meiniwati et al., 2014). Jamur $P$. grisea memiliki tiga unsur dinding sel yaitu kitin, glukan, dan proteoheteroglycan (Nakajima et al., 1970). Enzim kitinase dan selulase yang disekskresikan oleh rizobakteria mampu mendegradasi dinding sel patogen sehingga perkembangan patogennya terganggu (Quintao et al., 2015). Senyawa antibiotik menghambat pertumbuhan patogen melalui kontak langsung antara antagonis dengan patogen (Quintao et al., 2015). Hasil pengamatan uji antagonis tampak warna kuning antara pertemuan miselium bakteri antagonis $P$. flourescans dengan miselium $P$. grisea (Gambar 2). Hal ini menunjukkan bahwa jamur antagonis tersebut menghasilkan senyawa antibiotik. Menurut Santoso (2008) mekanisme antibiosis pada uji antagonis ditandai adanya warna kuning pada pertemuan miselium dengan jamur patogen.

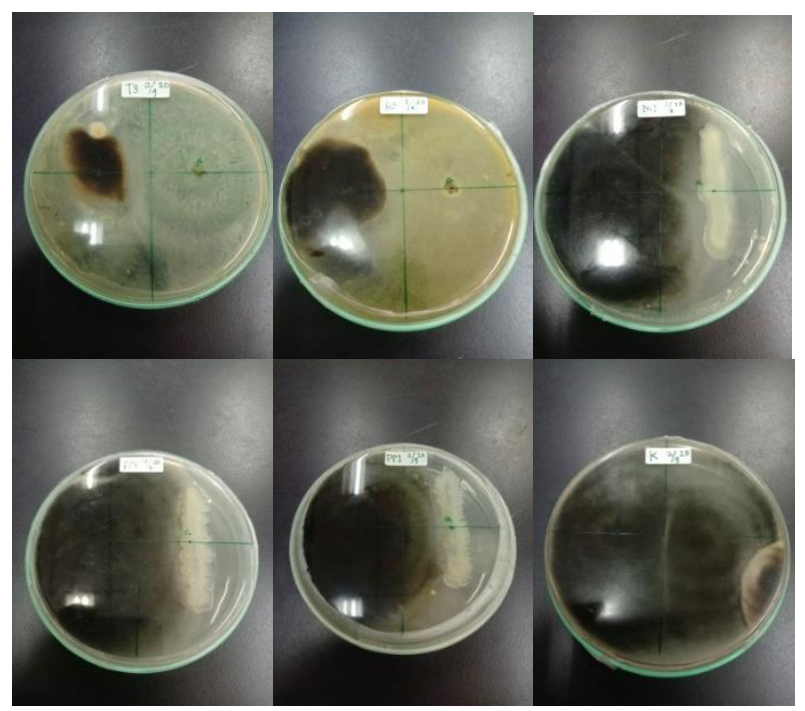

Gambar 1. Penekanan P.grisea pada perlakuan (a) PgT, (b) PgG; (c) PgB; (d) PgPf; (e) PgPp, dan (f) Kontrol

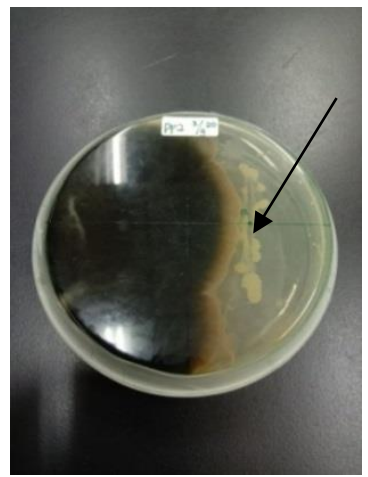

Gambar 2. Pengamatan Uji Antagonis $P$. grisea $\times P$. fluorescens (Sumber: Dokumentasi pribadi)

Mekanisme penghambatan jamur antagonis terhadap patogen menyatakan bahwa hasil pengamatan secara makroskopis menunjukkan respon hifa jamur patogen akibat interaksi dengan jamur antagonis. Pada perlakuan PgT yaitu terdapat adanya lilitan hifa, PgG hifa mengalami lisis dan adanya lilitan, $\mathrm{PgB}$ hifa mengalami mafolmasi, sedangkan pada perlakuan $\mathrm{PgPf}$ dan $\mathrm{PgPp}$ hifa mengalami lisis (Gambar 3). Jamur dari marga Trichoderma sp. yang mempunyai mekanisme kompetisi dan parasitisme, umumnya memiliki spektrum penghambatan yang lebih luas dan lebih kuat sehingga menyebabkan patogen tidak dapat tumbuh. Aktivitas parasitisme dari jamur antagonis marga Trichoderma sp. terhadap patogen $P$. grisea menghasilkan senyawa kimia yang bersifat toksik dan enzim yang mampu mendegradasi sel patogen (Benitez et al., 2004).

Hasil penelitian Habazar \& Yaherwandi (2006) pada pengendalian hayati menggunakan Trichoderma sp. menunjukkan bahwa hifa parasit Trichoderma sp. akan tumbuh sejajar dengan hifa patogen dan membentuk cabang-cabang samping seperti pengait di sekeliling hifa dan mampu menembus hifa patogen. Mekanisme hambatan dari marga Trichoderma sp. menyebabkan hifa patogen membesar dan lisis (Amaria et al., 2015). Hifa Trichoderma sp. dapat tumbuh berkembang dan membentuk konidia di dalam hifa patogen bahkan hifa Trichoderma sp. mampu menembus struktur istirahat patogen seperti sklerotia begitu juga dengan Gliocladium sp. seperti dijelaskan oleh Djarir (1993) bahwa Gliocladium sp. mampu memproduksi antibiosis yang dapat menghambat pertumbuhan hifa cendawan patogen. Intervensi hifa oleh Trichoderma sp. mengakibatkan adanya perubahan unsur kimia dan partikel pada dinding sel sehingga dapat memengaruhi permeabilitas dinding sel patogen (Dwiastuti et al., 2015). Hifa antagonis yang berhasil melakukan intervensi dan penetrasi akan menyerap sari makanan sehingga hifa cendawan patogen dapat mengecil dan mati (Dwiastuti et al., 2015).
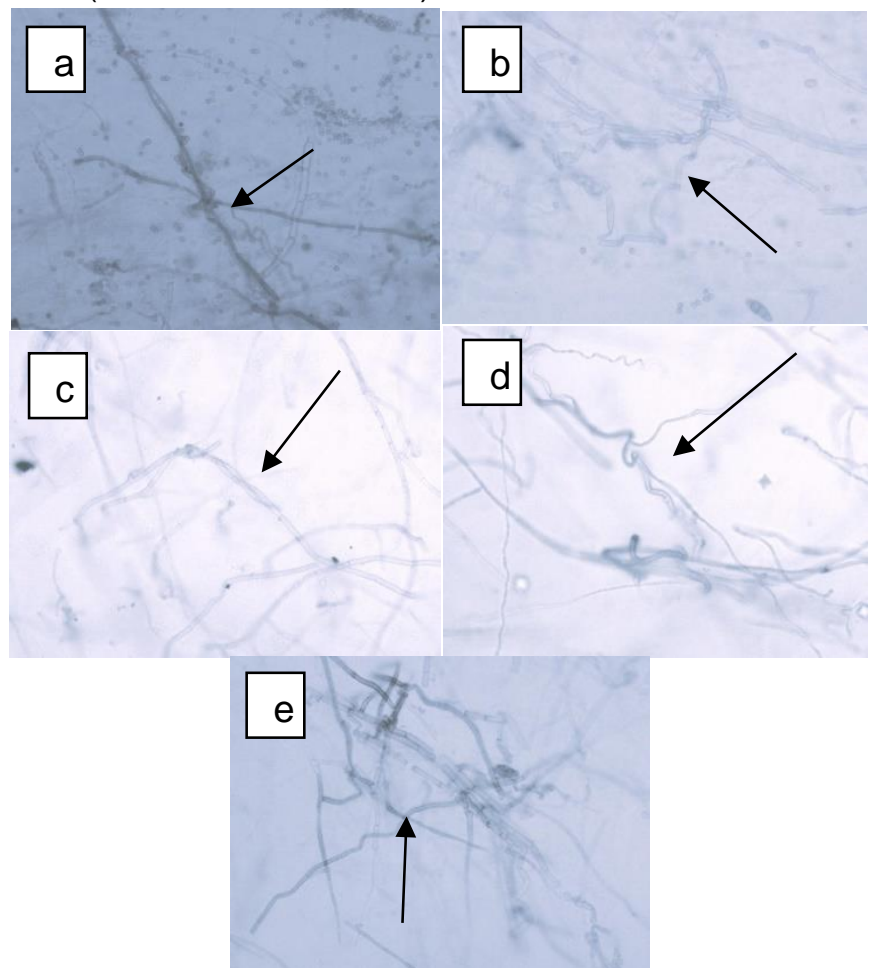

Gambar 3. Respon hifa jamur patogen akibat interaksi dengan jamur antagonis; (a) lilitan PgT; (b) lisis dan lilitan PgG; (c) mafolmasi hifa PgB; (d) lisis PgPf; (e) lisis PgPp

Sedangkan pada perlakuan $B$. subtilis, $P$. flourescans dan $P$. polymyxa menyebabkan hifa patogen lisis. Senyawa antifungal yang dihasilkan oleh bakteri secara umum mengakibatkan terjadinya pertumbuhan yang abnormal pada hifa (malformasi) patogen, yang ditunjukkan dengan pembengkakan dan pemendekan hifa yang mengakibatkan hifa tidak dapat berkembang 
dengan sempurna (Saylendra et al., 2015). Agus et al., (2013) menyatakan bahwa kemampuan suatu senyawa yang terdapat di dalam bakteri dapat mengendalikan jamur sehingga terganganggunya permeabilitas jamur dimana hal tersebut dapat menghambat produksi dan eksresi enzim ekstraseluler dari jamur dan penghambatan terjadi salah satunya diakibatkan oleh adanya lilis dari antagonis. Mekanisme lisis ditandai dengan berubahnya warna hifa cendawan patogen menjadi bening dan kosong, kemudian ada yang putus, dan akhirnya hancur (Gambar 3).

\section{KESIMPULAN}

Efikasi beberapa agens hayati mampu menghambat pertumbuhan dari cendawan $P$. grisea dimana dari beberapa agens hayati yang digunakan seperti Trichoderma sp. dan Gliocladium sp. mampu menghambat pertumbuhan dari patogen $P$. grisea penyebab penyakit blas secara sifnifikan yaitu sebesar $67.04 \%$ dan $51.85 \%$.

\section{UCAPAN TERIMA KASIH}

Penulis mengucapkan terimakasih Tika Dewi Munifah selaku Staf Laboratorium Fitopatologi Balai Besar Peramalan Organisme Penganggu Tumbuhan (BBPOPT) yang telah membantu dalam proses proses identifikasi P.grisea secara mikroskopis sehingga terlaksana dengan baik.

\section{DAFTAR PUSTAKA}

Amaria, W., Harni, R., \& Samsudin, S. (2015). Evaluasi jamur antagonis dalam menghambat pertumbuhan Rigidoporus microporus penyebab penyakit jamur akar putih pada tanaman karet. J. tanaman industri dan penyegar, 2(1), 51-60.

Badan Pusat Statistik [BPS]. (2020). Luas panen dan produksi padi pada tahun 2019. https://www.bps.go.id. Diakses pada tanggal 22 Juni 2020.

Baker, K. F. \& Cook, R. J. (1974). Biology control of plant pathogens. San Fransisco: W.H. Freeman and Co.

BBPADI. (2015). Penyakit blas padi. http://bbpadi.litbang.pertanian.go.id. Diakses pada tanggal 22 Juni 2020.

Benítez, T., Rincón, A.M., Limón, M.C., \& Codón, A.C. (2004). Biocontrol mechanisms of Trichoderma strains. Int Microbiol., 7(4), 249-60.

Djafaruddin. (2004), Dasar-dasar pengendalian penyakit tanaman. Penerbit Bumi Aksara, Jakarta

Djarir, M. (1993). Mikotoksin pangan. Kanisius, Yogyakarta.

Dwiastuti, M. E., Fajri, M. N. \& Yunimar. (2015). Potensi Trichoderma spp. sebagai agens pengendali Fusarium spp. penyebab penyakit layu pada tanaman stroberi (Fragaria $\mathrm{x}$ ananassa Dutch.). J. Hort. 25 (4): 331-339.

Elbert, W., Taylor, P.E., Andreae, M.O., \& Pöschl, U. (2007). Contribution of fungi to primary biogenic aerosols in the atmosphere: Wet and dry discharged spores, carbohydrates and inorganic ions. Atmos. Chem. Phys., 7: 4569-4588.

Goldfarb, A. H. (2013). Exercise and endogenous opiates. in endocrinology of physical activity and sport (pp. 21-36). Humana Press, Totowa, NJ.
Habazar, T. \& Yaherwandi. (2006). Pengendalian hayati hama dan penyakit tumbuhan. Andalas University Press, Padang.

Hasanuddin. (2003). Peningkatan peranan mikroorganisme dalam sistem pengendalian penyakit tumbuhan secara terpadu, Makalah Jurusan Hama dan Penyakit Tumbuhan Fakultas Pertanian Universitas Sumatera Utara, Medan.

Jaiganesh, V., Eswaran, A., Balabaskar, P., \& Kannan, C. (2007). Antagonistic activity of Serratia marcescens against Pyricularia oryzae. Notulae Botanicae Horti Agrobotanici Cluj-Napoca, 35(2), 48.

Kunst, F. \& Rapoport, G. (1995). Salt stress is an environmental signal affecting degradative enzyme synthesis in Bacillus subtilis. Journal of bacteriology, 177(9), 2403-2407.

Kurniawati, Y. (2012). Pengaruh Trichoderma viridae dan Pseudomonas fluorescens terhadap pertumbuhan Phytophthora palmivora Butl. pada berbagai media tumbuh. Skripsi. Universitas Lampung. Bandar Lampung. $60 \mathrm{hlm}$.

Kusumawati, D. E. \& Istiqomah. (2020). Potensi agensia hayati dalam menekan laju serangan penyakit blas (Pyricularia oryzae) pada tanaman padi. Jurnal Viabel Pertanian 14(2): 1-13.

Mahadtanapuk, S., Sanguansermsri, M., Cutler, R. W., Sardsud, V., \& Anuntalabhochai, S. (2007). Control of anthracnose caused by Colletotrichum musae on Curcuma alismatifolia Gagnep. using antagonistic Bacillus spp. American Journal of Agricultural and Biological Science.

Meiniwati., Khotimah, S. \& Mukarlina. (2014). Uji antagonis Pyricularia grisea Sacc. penyebab blas pada tanaman padi menggunakan jamur rizosfer isolat lokal. Jurnal Protobiont.3(1): $17-24$.

Murjoko. (2017). Analisis kinerja ekspor 5 komoditas perkebunan unggulan Indonesia Tahun 2012-2016. http://lpp.uad.ac.id. Diakses pada tanggal 6 Maret 2021.

Nakajima, T., Tamari, K., Matsuda, K., Tanaka, H., \& Ogasawara, N. (1970). Studies on the cell wall of Piricularia oryzae Part II. The Chemical Constituents of the Cell Wall. Agricultural and Biological Chemistry, 34(4), 553-560.

Nasution A. \& N. Usyati. (2015). Observasi ketahanan varietas padi lokal terhadap penyakit blas (Pyricularia grisea) di rumah kaca. Prosiding Seminar Nasional Masyarakat BIODIV Indonesia 1(1):19-22.

Nur'Aini, F., Sukamto, S., Wahyuni, D., Suhesti, R. G., \& Ayunin, Q. (2013). Penghambatan pertumbuhan Colletotrichum gloeosporioides oleh Trichoderma harzianum, Trichoderma koningii, Bacillus subtilis dan Pseudomonas fluorescens (growth inhibition of Colletotrichum gloeosporioides by Trichoderma harzianum, Trichoderma koningii, Bacillus subtilis and Pseudomonas fluorescens).

Octaviani, E. A., \& Achmad, H. E. (2015). Potensi Thrichoderma harzianum dan Gliocladium sp. sebagai agen hayati terhadap Botrydiplo penyebab penyakit mati pucuk pada jambon (Anthocephalus cadamba (Roxb). Miq). Jurnal Silvikultur Tropika, 
6(1), 27-32.

Octriana, L. (2016). Potensi agen hayati dalam menghambat pertumbuhan Phytium sp. secara in vitro. Buletin Plasma Nutfah, 17(2), 138-142.

Papavizas, C. G. (1985). Trichoderma and Gliocladium: biology ekology and potential for biological control. Ann. Rev. Phytophatology. 23: 23-54.

Paulitz, T. (1992). Biological control of damping-off disease wit seed treatmens. In E.C. Tjamos, G.C. Papavizas \& R.J. Cook (eds) Biological control of plant disease, Progress and challenges for the future. Plenum Press. New York.

Prasetyo, G., Ratih, S., Ivayani, I., \& Akin, H. M. (2017). Efektivitas Pseudomonas fluorescens dan Paenibacillus polymyxa terhadap keparahan penyakit karat dan hawar daun serta pertumbuhan tanaman jagung manis (Zea mays var. Saccharata). Jurnal Agrotek Tropika, 5(2): 102-108.

Quintao, V., Suprapta, D. N., Temaja, I. G. R. M., \& Khalimi, K. (2015). Potensi rizobakteri yang diisolasi dari rizosfer tanaman padi sebagai agen hayati untuk menghambat pertumbuhan jamur Pyricularia oryzae, penyebab penyakit blas pada tanaman padi. Journal of Agricultural Science and Biotechnology, 4(1).

Raka, I. G. (2006). Eksplorasi dan cara aplikasi agensia hayati Trichoderma sp. sebagai pengendali organisme pengganggu tumbuhan (OPT). Dinas Pertanian Tanaman Pangan UPTD Balai Proteksi Tanaman Pangan dan Holtikultura. Bali.

Rao, S. N. S. (1994). Mikroorganisme tanah dan pertumbuhan tanaman. UI Press, Jakarta.

Risthayeni, P., \& Zahara, F. (2018). Uji efektifitas jamur antagonis Trichoderma sp. dan Gliocladium sp. untuk mengendalikan penyakit pokahbung (Fusarium moniliforme) pada tanaman tebu (Saccharum officinarum). Jurnal Online Agroekoteknologi, 6(2): 339-344.

Santoso \& A. Nasution. (2008). Pengendalian penyakit blas dan penyakit cendawan lainnya. Buku Padi 2. HIm. 531- 563.
Saylendra, A., Rusbana, T. B. \& Herdiani, L. (2015). Uji antagonis Pseudomonas sp. asal endofit perakaran padi terhadap penyakit blas (Pyricularia oryzae) secara in vitro. Agrologia. 4(2): 83-87.

Sopialena, S., Suyadi, S., Sofian, S., Tantiani, D., \& Fauzi, A. N. (2020). Efektivitas cendawan endofit sebagai pengendali penyakit blast pada tanaman padi (Oryza sativa). Agrifor: J. Ilmu Pertanian dan Kehutanan, 19(2), 355-366.

Sopialena. (2018). Pengendalian hayati dengan memberdayakan potensi mikroba. https://faperta.unmul.ac.id/web/wpcontent/uploads/2 019/01/PENGENDALIAN-HAYATI-dengan-

Memberdayakan-Potensi-Mikroba.pdf. Diakses pada tanggal 19 November 2020.

Suganda, T., E. Yulia, F. Widiantini \& Hersanti. (2016). Intensitas penyakit blas (Pyricularia oryzae Cav.) pada padi varietas Ciherang di lokasi endemik dan pengaruhnya terhadap kehilangan hasil. Jurnal Agrikultura 27(3):154-159.

Susanto, A., \& Prasetyo, A. E. (2013). Respons Curvularia lunata penyebab penyakit bercak daun kelapa sawit terhadap berbagai fungisida. Jurnal Fitopatologi Indonesia, 9(6), 165-165.

Trigiano, R. N., Windham, M. T., \& Windham, A. S. (2008). Plant pathology: concepts and laboratory exercises (p. 558). Second Edition. New York: CRC Press

Warsani, H. (2013). Kajian pemanfaatan lahan sawah di kecamatan Kuantan Tengah kabupaten Kuantan Singingi (Doctoral dissertation, Universitas Pendidikan Indonesia).

Yulianto. 2017. Pengendalian penyakit blas secara terpadu pada tanaman padi. http://pangan.litbang.pertanian.go.id/files/03IPTEK12-01-2017-Yulianto.pdf. Diakses pada tanggal 6 Maret 2021.

Zuraidah, Nida, Q. \& Wahyuni, S. (2020). Uji antagonis bakteri terhadap cendawan patogen penyakit blas. Jurnal Biotik. 8(1): 37-47. 